medRxiv preprint doi: https://doi.org/10.1101/2021.06.25.21253647; this version posted June 30, 2021. The copyright holder for this preprint (which was not certified by peer review) is the author/funder, who has granted medRxiv a license to display the preprint in perpetuity.

\title{
1 Word counts
}

2 Text: 2,831

3 Abstract: 275

4 Title: Racial/ethnic-based spirometry reference equations: Are they accurate for admixed

5 populations?

6 Running head: Racial/Ethnic-Based Spirometry: Accuracy for Admixed

8 Author list: Jonathan Witonsky, MD; Jennifer R. Elhawary, MS; Celeste Eng, BS; José R.

9 Rodríguez-Santana, MD; Luisa N. Borrell ${ }^{\#}$, DDS, PhD; and Esteban G. Burchard" ${ }^{\#}$ MD, MPH

$10 \quad$ \#Shared senior authors.

11 Affiliations: From the Department of Pediatrics (Dr Witonsky), Department of Medicine (Ms

12 Elhawary and Ms Eng), and Department of Medicine and Department of Bioengineering and

13 Therapeutic Sciences (Dr Burchard), University of California, San Francisco, San Francisco,

14 CA; Centro de Neumología Pediátrica (Dr Rodríguez-Santana), San Juan, PR; and the

15 Department of Epidemiology and Biostatistics, Graduate School of Public Health and Health

16 Policy (Dr Borrell), City University of New York, New York, NY.

17 Correspondence to: Jonathan Witonsky, MD, Department of Pediatrics, University of

18 California, San Francisco, 550 16th Street, 4th Floor, San Francisco, CA, 94143; e-mail:

19 jonathan.witonsky@ucsf.edu

20 Funding information: This work was supported in part by the Sandler Family Foundation; the

21 American Asthma Foundation; the RWJF Amos Medical Faculty Development Program; Harry

22 Wm. and Diana V. Hind Distinguished Professor in Pharmaceutical Sciences II; the National

23 Institutes of Health, National Heart, Lung, and Blood Institute [R01HL117004, 1X01HL134589, 
medRxiv preprint doi: https://doi.org/10.1101/2021.06.25.21253647; this version posted June 30, 2021. The copyright holder for this preprint (which was not certified by peer review) is the author/funder, who has granted medRxiv a license to display the preprint in perpetuity. All rights reserved. No reuse allowed without permission.

RACIAL/ETHNIC-BASED SPIROMETRY: ACCURACY FOR ADMIXED

24 R01HL128439, R01HL135156, R01HL141992]; the National Institute of Environmental Health

25 Sciences [R01ES015794, R21ES24844]; the National Institute on Minority Health and Health

26 Disparities [R01MD010443, R56MD013312]; the National Human Genome Research Institute

27 [U01HG009080]; the National Institute of General Medical Sciences [T32GM007546], and the

28 UCSF Pediatric Allergy, Immunology, and Bone Marrow Transplantation Division. The content

29 of this publication is solely the responsibility of the authors and does not necessarily reflect the

30 views or policies of the Department of Health and Human Services, nor does mention of trade

31 names, commercial products, or organizations imply endorsement by the U.S. government. 
medRxiv preprint doi: https://doi.org/10.1101/2021.06.25.21253647; this version posted June 30, 2021. The copyright holder for this preprint (which was not certified by peer review) is the author/funder, who has granted medRxiv a license to display the preprint in perpetuity.

All rights reserved. No reuse allowed without permission.

RACIAL/ETHNIC-BASED SPIROMETRY: ACCURACY FOR ADMIXED

\section{ABSTRACT}

33 BACKGROUND: Variation in genetic ancestry among admixed racial/ethnic groups may

34 influence the fit of guideline-recommended spirometry reference equations, which rely on self-

35 identified race/ethnicity.

36 RESEARCH QUESTION: What is the influence of genetic ancestry on the fit of the guideline-

37 recommended racial/ethnic-based spirometry reference equations in populations of genetically

38 admixed children?

STUDY DESIGN AND METHODS: Cross-sectional fit of guideline-recommended

40 racial/ethnic-based spirometry reference equations was evaluated in control subjects from case-

41 control studies of asthma. Anthropometry, blood samples, and spirometric measurements were

42 obtained in 599 healthy admixed children, aged 8 to 21 -years. Genetic ancestry was estimated

43 using genome-wide genotype data. Equation fit was determined as a mean z-score between - 0.5

44 and 0.5 and assessed in self-identified African American $(\mathrm{N}=275)$ and Puerto Rican $(\mathrm{N}=324)$

45 children using the distribution to determine cut points of genetic ancestry.

46 RESULTS: For African American children, African American-derived equations fit for

47 predicting $\mathrm{FEV}_{1}$ and $\mathrm{FVC}$ in those with an African ancestry above the median (81-100\%),

48 whereas composite equations for "other/mixed" populations fit for predicting $\mathrm{FEV}_{1}$ and FVC in

49 those with an African ancestry below the median (31-81\%). Among Puerto Rican children,

50 White-derived equations fit for predicting $\mathrm{FEV}_{1}$, and the composite equations fit for predicting

51 FVC for those with African ancestry above the median (21-88\%). In contrast, in Puerto Rican

52 children with African ancestry below the median (6-21\%), only equations derived in Whites

53 provide an adequate fit. 
medRxiv preprint doi: https://doi.org/10.1101/2021.06.25.21253647; this version posted June 30, 2021. The copyright holder for this preprint (which was not certified by peer review) is the author/funder, who has granted medRxiv a license to display the preprint in perpetuity. All rights reserved. No reuse allowed without permission.

RACIAL/ETHNIC-BASED SPIROMETRY: ACCURACY FOR ADMIXED

54 INTERPRETATION: Guideline-recommended spirometry reference equations yielded biased

55 estimates of lung function in admixed populations with high variation of African ancestry.

56 Spirometry is due for reference equations that incorporate genetic ancestry, either for more

57 precise application of the current equations or the derivation and utilization of new equations. 
medRxiv preprint doi: https://doi.org/10.1101/2021.06.25.21253647; this version posted June 30, 2021. The copyright holder for this preprint (which was not certified by peer review) is the author/funder, who has granted medRxiv a license to display the preprint in perpetuity.

All rights reserved. No reuse allowed without permission.

RACIAL/ETHNIC-BASED SPIROMETRY: ACCURACY FOR ADMIXED

INTRODUCTION

59 There has been great debate over the use of racial/ethnic classification in medicine and

biomedical research. ${ }^{1-3}$ Presently, pulmonary function testing is one of the few clinical

61 applications where self-reported race/ethnicity is used to define a "normal" range. Normative

62 equations of lung function have been developed by testing large populations categorized by self-

63 reported race/ethnicity. ${ }^{4,5}$ However, many populations have ancestral contributions from multiple

64 continents (i.e., genetically admixed) and, as a result, self-identified racial and ethnic categories

65 may not fully capture an individual's genetic ancestry. ${ }^{6-9}$ Therefore, using self-reported

66 race/ethnicity may result in misclassifying individuals with respect to the normal range for

67 physiologic lung measures if the latter are more dependent on ancestry. ${ }^{10}$ This error could lead to

68 inaccuracies in evaluating individual pulmonary function.

69 The two most widely employed sets of spirometry reference equations used in pulmonary

70 function testing, and those recommended by American Thoracic Society and European

71 Respiratory Society (ATS/ERS) guidelines, are the third National Health and Nutrition

72 Examination Survey (NHANES III) equations, derived in White, African American, and

73 Mexican American adults and children aged 8-80 years, and the Global Lung Function Initiative

74 (GLI) equations, derived in White, African American, and North and South East Asian adults

75 and children aged 3-95 years. ${ }^{4,5,11}$ GLI also offers a composite equation-an average of the four

76 population-specific GLI equations-for use in multiracial or unrepresented populations. These

77 guideline-recommended spirometry reference equations adjust for clinically important

78 differences in normal lung function observed between racial/ethnic groups. Selecting an

79 inappropriate reference equation —or ignoring race/ethnicity by using a one-size-fits-all

80 approach — can cause unintended clinical consequences, including errors and delays in disease 
medRxiv preprint doi: https://doi.org/10.1101/2021.06.25.21253647; this version posted June 30, 2021. The copyright holder for this preprint (which was not certified by peer review) is the author/funder, who has granted medRxiv a license to display the preprint in perpetuity.

All rights reserved. No reuse allowed without permission.

\section{RACIAL/ETHNIC-BASED SPIROMETRY: ACCURACY FOR ADMIXED}

81 detection and medical management, misclassification of disease severity, denial of disability

82 claims, and ineligibility for life-saving treatments such as transplants and other surgeries. ${ }^{12-20}$

83 Several studies have demonstrated that the guideline-recommended lung function equations are

84 well-fitted to populations similar to those in which they were derived. ${ }^{16,21-25}$ However, to date,

85 none of these studies have evaluated equation fit after considering intra-population variation in

86 genetic ancestry, which we have demonstrated is associated with lung function in African

87 Americans and Latinos. ${ }^{26-28}$ Herein, we evaluate the guideline-recommended White, African

88 American, Mexican American, and composite reference equations for two independent

89 genetically admixed populations of African American and Puerto Rican children. Specifically,

90 we assessed guideline-recommended lung function equation fit in each population and

91 investigated their fit after classifying these populations using their genetic ancestry distribution.

\section{METHODS}

\section{Study Populations}

94 Spirometric predictions and genetic ancestry proportions were calculated using clinical and

95 genetic data from healthy control subjects among two case-control studies of asthma conducted

96 between 2006 and 2014: the Genes-environments \& Admixture in Latino Americans (GALA II)

97 study and the Study of African Americans, Asthma, Genes, \& Environments (SAGE). ${ }^{29}$ Subjects

98 were aged 8 to 21 -years old at the time of recruitment and were healthy with no reported history

99 of lung disease, asthma or allergies, use of medication for allergies, or any symptoms of

100 wheezing or shortness of breath during their lifetime. Parents and grandparents of study subjects

101 self-identified as Puerto Rican in GALA II or African American in SAGE. GALA II subjects

102 were recruited from five urban study centers throughout the U.S. (Chicago, Bronx, Houston, San 
medRxiv preprint doi: https://doi.org/10.1101/2021.06.25.21253647; this version posted June 30, 2021. The copyright holder for this preprint (which was not certified by peer review) is the author/funder, who has granted medRxiv a license to display the preprint in perpetuity.

All rights reserved. No reuse allowed without permission.

RACIAL/ETHNIC-BASED SPIROMETRY: ACCURACY FOR ADMIXED

103 Francisco Bay Area, and Puerto Rico) and SAGE subjects were recruited from the San Francisco

104 Bay Area.

105 All participants provided written consent to being in the study. Consent was obtained from all

106 participants 18-years and older and parent/legal guardians of minor participants. The study

107 protocols for both GALA II and SAGE were approved by the University of California, San

108 Francisco (UCSF) Human Research Protection Program Institutional Review Board (IRB) and

109 all institutions participating in recruitment obtained the appropriate approvals from their IRBs for

110 recruitment related activity.

111 In total, 3,226 children without asthma were enrolled in the two studies (2,538 in GALA II and

112688 in SAGE) with complete spirometry and genome-wide genetic data available for 1,049

113 children. After exclusion criteria (Figure 1) were applied, 599 children remained: 275 African

114 American children and 324 Puerto Rican children.

\section{Assessments}

116 Spirometric measurements were collected on all subjects with testing performed in accordance

117 with ATS recommendations. ${ }^{30}$ Samples were genotyped with the Affymetrix Axiom® LAT1

118 array (World Array 4, Affymetrix, Santa Clara, CA), which includes 817,810 single nucleotide

119 polymorphisms (SNPs). This array was designed to capture genetic variation in African-descent

120 populations such as African Americans and Latinos. ${ }^{31}$ The genetic ancestry of each study

121 participant was determined using an unsupervised analysis in the ADMIXTURE software

122 package, as described elsewhere. ${ }^{28}$ 
medRxiv preprint doi: https://doi.org/10.1101/2021.06.25.21253647; this version posted June 30, 2021. The copyright holder for this preprint (which was not certified by peer review) is the author/funder, who has granted medRxiv a license to display the preprint in perpetuity.

All rights reserved. No reuse allowed without permission.

\section{RACIAL/ETHNIC-BASED SPIROMETRY: ACCURACY FOR ADMIXED}

123 We examined the distribution of genetic ancestry in each population and used the median for

124 African ancestry to classify African American and Puerto Rican populations into two groups,

125 "greater than median" and "less than or equal to median," based on African ancestry. Median

126 African ancestry cut points were $81.3 \%$ (range: 30.7-100\%) for African American children and

$127 \quad 21.3 \%$ (range: 6.4-87.5\%) for Puerto Rican children. Reference equation fit was independently

128 assessed in the African American population $(\mathrm{N}=275)$, the African American population with

129 African ancestry greater than the population's median $(\mathrm{N}=137)$, the African American

130 population with African ancestry less than or equal to the population median $(\mathrm{N}=138)$, the

131 Puerto Rican population $(\mathrm{N}=324)$, the Puerto Rican population with African ancestry greater

132 than the population's median $(\mathrm{N}=162)$, and the Puerto Rican population with African ancestry

133 less than or equal to the population median $(\mathrm{N}=162)$.

\section{Statistical Analyses}

135 Demographic characteristics were compared within each subpopulation using the Student's t-test

136 for normally distributed continuous variables, the Wilcoxon Rank Sum Test for non-normally

137 distributed continuous variables, and chi-squared statistic for dichotomous variables.

138 Consistent with previous studies, ${ }^{32,33}$ cross-sectional fit of the equations was determined by

139 calculating $\mathrm{FEV}_{1}$ and $\mathrm{FVC}$ z-scores. The $\mathrm{z}$-score means for $\mathrm{FEV}_{1}$ and $\mathrm{FVC}$ were calculated using

140 the NHANES III White, African American, and Mexican American equations and the GLI

141 White, African American, and composite equations. Because all study participants were healthy

142 with assumed normal lung function, an equation was deemed "best fit" when the mean z-score

143 was closest to zero (perfect fit being a mean z-score of zero), and an equation was deemed to

144 have "sufficient fit" if the mean z-score was between -0.5 and 0.5 using two one-sided t-tests 
medRxiv preprint doi: https://doi.org/10.1101/2021.06.25.21253647; this version posted June 30, 2021. The copyright holder for this preprint (which was not certified by peer review) is the author/funder, who has granted medRxiv a license to display the preprint in perpetuity. All rights reserved. No reuse allowed without permission.

RACIAL/ETHNIC-BASED SPIROMETRY: ACCURACY FOR ADMIXED

145 (TOST) for equivalence. ${ }^{21,34,35}$ Assessment of significance testing for TOST was performed

146 using $95 \%$ confidence intervals and $P$-values. ${ }^{36}$ An equation was deemed appropriate if it

147 provided sufficient fit for both $\mathrm{FEV}_{1}$ and $\mathrm{FVC}$. A sensitivity analysis was performed assessing fit

148 using genetic ancestry tertile, quartile, and quintile distributions. To assess for misclassification,

149 the proportion of subjects with observed spirometry data below the lower limit of normal (LLN),

150 which corresponds to the $5^{\text {th }}$ percentile $(\mathrm{z}$-score $=-1.65)$ of predicted values, were also evaluated

151 for $\mathrm{FEV}_{1}$ and FVC. Data analyses were conducted using R. ${ }^{33}$

\section{RESULTS}

153 Table 1 summarizes general characteristics of participants in each racial/ethnic group. Sex, age,

154 height, and weight distributions were comparable across each subpopulation. Lung function, as

155 measured by mean z-scores for $\mathrm{FEV}_{1}$ and $\mathrm{FVC}$, was higher for African American $\left(\mathrm{zFEV}_{1}: 0.41\right.$,

156 zFVC: 0.56) and Puerto Rican $\left(\mathrm{zFEV}_{1}: 0.69, \mathrm{zFVC}: 0.55\right)$ subpopulations with African ancestry

157 less than or equal to the median than African American $\left(\mathrm{zFEV}_{1}: 0.29, \mathrm{zFVC}\right.$ : 0.43) and Puerto

158 Rican $\left(\mathrm{zFEV}_{1}: 0.43, \mathrm{zFVC}: 0.23\right)$ subpopulations with African ancestry greater than the median.

159 These differences in lung function between subpopulations were statistically significant for the

160 Puerto Rican children but not for the African American children.

\section{Genetic Ancestry Proportions}

162 When comparing subpopulations according to the median distribution, the means ( \pm standard

163 deviation, or SD) of African ancestry were $73.2 \%( \pm 9.6 \%)$ and $85.9 \%( \pm 3.2 \%)$ for African

164 American children below and above the median, respectively (Table 1). These values were

$16515.1 \%( \pm 3.3 \%)$ and $30.2 \%( \pm 9.8 \%)$ among Puerto Rican children. Figure 2 shows the 
medRxiv preprint doi: https://doi.org/10.1101/2021.06.25.21253647; this version posted June 30, 2021. The copyright holder for this preprint (which was not certified by peer review) is the author/funder, who has granted medRxiv a license to display the preprint in perpetuity. All rights reserved. No reuse allowed without permission.

RACIAL/ETHNIC-BASED SPIROMETRY: ACCURACY FOR ADMIXED

European, African, and Native American genetic admixture in the African American and Puerto

167 Rican populations.

\section{Fit to African American Children}

Table 2 a provides equation fit to spirometric measurements in the study population and subpopulations of African American children based on genetic ancestry distribution. The NHANES III equations derived in African Americans and the GLI composite equations were

172 appropriate for African American children at the population level, providing sufficient fit for 173 predicting $\mathrm{FEV}_{1}$ and FVC. The mean z-scores were 0.17 (95\% CI: 0.06 to 0.28) for predicting

$174 \mathrm{FEV}_{1}(2.5 \%$ below the LLN) and 0.34 (95\% CI: 0.23 to 0.45$)$ for predicting FVC (1.8\% below

175 the LLN) using the NHANES III African American equations, whereas they were -0.32 (95\% CI:

$176-0.43$ to -0.20$)$ for predicting $\mathrm{FEV}_{1}(5.8 \%$ below the LLN) and -0.14 (95\% CI: -0.27 to -0.02$)$ for

177 predicting FVC (6.2\% below the LLN) using GLI composite equations. When using the African

178 genetic ancestry median to classify African American children, only the GLI composite

179 equations were appropriate for predicting both $\mathrm{FEV}_{1}$ and $\mathrm{FVC}$ with mean $\mathrm{z}$-scores of $-0.25(95 \%$

180 CI: -0.42 to -0.09$)$ for $\mathrm{FEV}_{1}(5.8 \%$ below the LLN) and -0.08 (95\% CI: -0.25 to 0.10$)$ for FVC

181 (5.8\% below the LLN) for African American children classified below the median. In contrast,

182 for African American children with African ancestry above the median, the NHANES III

183 equations derived in African American children were appropriate for predicting $\mathrm{FEV}_{1}(0.11$;

$18495 \%$ CI: -0.04 to $0.26 ; 2.9 \%$ below the LLN) and FVC $(0.27 ; 95 \%$ CI: 0.10 to $0.43 ; 2.9 \%$ below

185 the LLN). Figure 3a provides the fit for the NHANES III and GLI equations using other

186 distribution cut points of African ancestry in addition to the median. The figure underscores the

187 poor fit of the equations in African American children when using other African ancestry cut

188 points. 
medRxiv preprint doi: https://doi.org/10.1101/2021.06.25.21253647; this version posted June 30, 2021. The copyright holder for this preprint (which was not certified by peer review) is the author/funder, who has granted medRxiv a license to display the preprint in perpetuity.

All rights reserved. No reuse allowed without permission.

RACIAL/ETHNIC-BASED SPIROMETRY: ACCURACY FOR ADMIXED

Fit to Puerto Rican Children

At the population level, the GLI equations derived in Whites were appropriate for Puerto Rican children with mean z-scores of -0.06 (95\% CI: -0.19 to 0.06$)$ for predicting $\mathrm{FEV}_{1}(6.8 \%$ below the LLN) and -0.33 (95\% CI: -0.46 to -0.21$)$ for predicting FVC (11.1\% below the LLN) (Table 2b). For Puerto Rican children with African ancestry below and above the median, the GLI and NHANES III equations derived in Whites fit for predicting $\mathrm{FEV}_{1}$. The White-derived equations only fit for predicting FVC among Puerto Rican children with African ancestry below the median. The GLI composite equation fit for predicting FVC in the subpopulation of Puerto Rican

197 children with African ancestry above the median. However, the GLI composite equations underestimated $\mathrm{FEV}_{1}$ predictions among those with African ancestry below the median (Figure 3b). In Puerto Rican children with African ancestry below the median, both GLI and NHANES III equations derived in Whites were appropriate for predicting $\mathrm{FEV}_{1}$ and $\mathrm{FVC}$.

\section{DISCUSSION}

Pulmonary function testing is one of the few applications in clinical medicine where selfidentified race/ethnicity is used to predict normative values. Our findings confirm previous

204 observations that race/ethnicity-based equations can misestimate lung function after considering 205 intra-population variation in African ancestry. ${ }^{26}$ The influence of genetic ancestry on guideline-

206 recommended equation fit is relevant to African American and Puerto Rican populations in

207 which there are especially wide distributions in the proportions of African ancestry. ${ }^{37}$

208 Consequently, the guideline-recommended equations may exacerbate inequities in respiratory

209 health, which disproportionately affect the very populations for whom the race/ethnicity-based

210 spirometry equations are the least precise. ${ }^{38}$ As a result, these populations are most prone to 
medRxiv preprint doi: https://doi.org/10.1101/2021.06.25.21253647; this version posted June 30, 2021. The copyright holder for this preprint (which was not certified by peer review) is the author/funder, who has granted medRxiv a license to display the preprint in perpetuity.

All rights reserved. No reuse allowed without permission.

RACIAL/ETHNIC-BASED SPIROMETRY: ACCURACY FOR ADMIXED

211 underestimated lung function predictions. Misestimated lung function may result in delays of

212 disease detection or overestimated lung function predictions, which can result in unnecessary

213 treatment. This is of critical concern given that African American and Latino/Hispanic children

214 collectively make up approximately $40 \%$ of all children in the United States. ${ }^{39}$

215 Previous studies have validated the use of the GLI equations derived in African American

216 populations for use in African and African American children. ${ }^{22,40}$ Our findings for African

217 American children in this study were consistent with those studies, although only for the total

218 population and ignoring African ancestry variation. After considering the variation in African

219 ancestry, the guideline-recommended equations derived in African American populations were

220 no longer well-fitted for predicting lung function in African American children with African

221 ancestry below the population's median. Only the GLI composite equation-an equation derived

222 as the average of all GLI data for use in multiracial or unrepresented populations-was

223 appropriately fitted for this subpopulation. This finding suggests that inappropriate spirometry

224 reference equations might be used for as many as half of all African American children, and

225 further illustrates how intra-population variation in African ancestry limits the clinical utility of a

226 single reference equation for an entire genetically admixed group.

227 In this study, the GLI equations derived in Whites were appropriate for the study population of

228 Puerto Rican children. This was an unexpected finding given that the largest study of reference

229 equation fit for Latino/Hispanic adults found the GLI White equations overestimated lung

230 function among adults who self-identified as Puerto Rican. ${ }^{18}$ The finding was also contrary to the

231 assumption that the GLI composite equation would be most appropriate for Puerto Ricans, a

232 population not represented by the four groups in which the GLI equations were derived.

233 Corroborating prior studies showing that African ancestry is inversely associated with lung 
medRxiv preprint doi: https://doi.org/10.1101/2021.06.25.21253647; this version posted June 30, 2021. The copyright holder for this preprint (which was not certified by peer review) is the author/funder, who has granted medRxiv a license to display the preprint in perpetuity.

All rights reserved. No reuse allowed without permission.

RACIAL/ETHNIC-BASED SPIROMETRY: ACCURACY FOR ADMIXED

234 function in Puerto Rican individuals, ${ }^{27,28}$ the GLI White equations were not appropriate for

235 Puerto Rican children with African ancestry above the population's median. In this

236 subpopulation, no equation was appropriately fitted for predicting both $\mathrm{FEV}_{1}$ and $\mathrm{FVC}$,

237 suggesting that as many as half of all Puerto Rican children are being misclassified for these

238 measures. The lack of an appropriate equation for Puerto Rican children with more African

239 ancestry is especially problematic considering that asthma prevalence and mortality are highest

240 among Puerto Ricans compared to other racial/ethnic groups. ${ }^{41,42}$ Puerto Ricans have wide-

241 ranging proportions of genetic ancestry and self-identify across the spectrum of the U.S. Census

242 racial categories, making the population ideally suited to the ongoing study of race/ethnicity and

243 genetic ancestry as predictors of lung function. ${ }^{37,43,44}$

244 There are some important limitations of this study. First, after classifying the populations by

245 genetic ancestry distribution, the sample sizes were below what is recommended for spirometry

246 equation validation studies. ${ }^{45}$ Consequently, equations deemed a poor fit for a subpopulation

247 resulted because this study was underpowered to detect significance when using specified TOST

248 criterion. However, to address this limitation, a sensitivity analysis demonstrated how mean z-

249 scores tended to trend in the serially stratified subpopulations, revealing the continuous influence

250 of ancestry on equation fit. Second, the study did not include the ratio of $\mathrm{FEV}_{1}$ to FVC

251 (FEV $1 / \mathrm{FVC})$, which is the most commonly used outcome to assess airway obstruction. The

$252 \mathrm{FEV}_{1} / \mathrm{FVC}$ ratio was excluded because prior reports suggest that racial/ethnic reductions in $\mathrm{FEV}_{1}$

253 and FVC are proportional and, therefore, the ratio is independent of race/ethnicity. ${ }^{5,22,46,47}$ Third,

254 our findings are not generalizable to adults because the analysis was performed exclusively in

255 children aged 18-21. Lastly, our results were not replicated in other populations of African 
medRxiv preprint doi: https://doi.org/10.1101/2021.06.25.21253647; this version posted June 30, 2021. The copyright holder for this preprint (which was not certified by peer review) is the author/funder, who has granted medRxiv a license to display the preprint in perpetuity.

All rights reserved. No reuse allowed without permission.

\section{RACIAL/ETHNIC-BASED SPIROMETRY: ACCURACY FOR ADMIXED}

256 American and Puerto Rican children, an essential next step in the evaluation of the guideline-

257 recommended equations.

258 Despite these limitations, this is the first study assessing the influence of genetic ancestry on the

259 applicability of guideline-recommended race/ethnicity-based spirometry reference equations for

260 admixed populations. This study shows that the use of guideline-recommended spirometry

261 reference equations in admixed populations is limited by intra-population variation in genetic

262 ancestry. In addition, this study contributes to the ongoing debate regarding the use of

263 race/ethnicity in clinical algorithms by demonstrating that race/ethnicity, alone, is insufficient for

264 estimating lung function in a large proportion of minority children. ${ }^{19}$ We demonstrate that the

265 use of genetic ancestry data instead of race/ethnicity in lung function equations could improve

266 lung function prediction equations for admixed populations. That said, we recognize that

267 incorporating race/ethnicity captures essential epidemiologic information that relates to lung

268 function and overall clinical outcomes not captured by genetic ancestry. ${ }^{19}$

\section{INTERPRETATION}

270 This study demonstrates that guideline-recommended spirometry reference equations, which rely

271 on self-identified race/ethnicity, inconsistently fit homogenous racial/ethnic groups after

272 classifying these populations by their genetic ancestry distribution. Recent scientific advances

273 allow for estimates of genetic ancestry to be easily and inexpensively measured as exemplified

274 by direct-to-consumer genetic ancestry testing. Unfortunately, current clinical practice has been

275 slow to adopt and incorporate modern advances from the Human Genome Project, which was

276 started over thirty years ago. Accordingly, spirometry is due for reference equations that

277 incorporate genetic ancestry, either for more precise application of the current equations or the 
medRxiv preprint doi: https://doi.org/10.1101/2021.06.25.21253647; this version posted June 30, 2021. The copyright holder for this preprint (which was not certified by peer review) is the author/funder, who has granted medRxiv a license to display the preprint in perpetuity.

All rights reserved. No reuse allowed without permission.

RACIAL/ETHNIC-BASED SPIROMETRY: ACCURACY FOR ADMIXED

278 derivation and utilization of new equations. Meanwhile, the increasing availability of genetic

279 data in the clinical setting can be leveraged to guide selection of the most appropriate spirometry

280 reference equation. Our findings suggest that African American children with African ancestry

281 above $80 \%$ are best fit by equations derived in African American populations, whereas those

282 with African ancestry below $80 \%$ are best fit by the GLI composite equation. Puerto Rican

283 children with African ancestry below $20 \%$ are best fit by equations derived in White populations.

284 However, there is no appropriately fitted equation for Puerto Rican children with African

285 ancestry above $20 \%$. As a result, extra caution must be taken when choosing a spirometry

286 reference equation and interpreting its results among racially/ethnically diverse populations.

287 Racially/ethnically diverse individuals might be best served if their spirometric measurements

288 are evaluated using multiple equations, with each result taken in the context of clinical

289 symptoms.

290 Acknowledgments

291 Author contributions: J. W. contributed to the conception and design of the work, analysis and

292 interpretation of the data, and drafting and revision of the manuscript. C. E. contributed to the

293 acquisition of data. J. R. E., J. R. R.-S., L. N. B., and E. G. B.: contributed to the analysis and

294 interpretation of the data, drafting and revision of the manuscript, and critical review of the

295 manuscript.

297 Other contributions: The authors thank the participants and their families for their contribution,

298 as well as the health care professionals and clinics for their support and participation in the

299 Genes-environments \& Admixture in Latino Americans Study and the Study of African 
medRxiv preprint doi: https://doi.org/10.1101/2021.06.25.21253647; this version posted June 30, 2021. The copyright holder for this preprint

(which was not certified by peer review) is the author/funder, who has granted medRxiv a license to display the preprint in perpetuity.

All rights reserved. No reuse allowed without permission.

RACIAL/ETHNIC-BASED SPIROMETRY: ACCURACY FOR ADMIXED

300 Americans, Asthma, Genes \& Environments. In particular, the authors thank the study

301 coordinator Sandra Salazar and the recruiters who obtained the data: Kelley Meade, MD, Adam

302 Davis, MPH, MA, Lisa Caine, Emerita Brigino-Buenaventura, MD, Duanny Alva, MD, Gaby

303 Ayala-Rodriguez, Ulysses Burley, Elizabeth Castellanos, Jaime Colon, Denise DeJesus, Iliana

304 Flexas, Blanca Lopez, Brenda Lopez, MD, Louis Martos, Vivian Medina, Juana Olivo, Mario

305 Peralta, Esther Pomares, MD, Jihan Quraishi, Johanna Rodriguez, Shahdad Saeedi, Dean Soto,

306 Ana Taveras, and Emmanuel Viera. The authors would also like to thank Andrew Zeiger, Oona

307 Risse-Adams, María G. Contreras, Fernando Picazo, MD, Martin Rofael, MD, Angel C. Y. Mak,

$308 \mathrm{PhD}$, Donglei Hu, PhD, Scott Huntsman, MS, Eric Wohlford, MD, PhD, Sam S. Oh, PhD, MPH,

309 Maria Pino-Yanes, PhD, L. Keoki Williams, MD, MPH, Michael A. Lenoir, MD, Noah A.

310 Zaitlen, PhD, Elad Ziv, MD, Thomas Nuckton, MD, Christopher Gignoux, PhD, and Joshua

311 Galanter, MD for their advice on project conception and analysis. 
medRxiv preprint doi: https://doi.org/10.1101/2021.06.25.21253647; this version posted June 30, 2021. The copyright holder for this preprint (which was not certified by peer review) is the author/funder, who has granted medRxiv a license to display the preprint in perpetuity. All rights reserved. No reuse allowed without permission.

RACIAL/ETHNIC-BASED SPIROMETRY: ACCURACY FOR ADMIXED

\section{References}

1. Burchard EG, Ziv E, Coyle N, et al. The importance of race and ethnic background in biomedical research and clinical practice. N Engl J Med 2003;348(12):1170-1175.

2. Phimister EG. Medicine and the racial divide. N Engl J Med 2003;348(12):1081-1082.

3. Cooper RS, Kaufman JS, Ward R. Race and genomics. N Engl J Med 2003;348(12):11661170.

4. Hankinson JL, Odencrantz JR, Fedan KB. Spirometric Reference Values from a Sample of the General U.S. Population. Am J Respir Crit Care Med 1999;159(1):179-187.

5. Quanjer PH, Stanojevic S, Stocks J, Cole TJ. GLI-2012 All-Age Multi-Ethnic Reference Values for Spirometry. :15.

6. The use of racial, ethnic, and ancestral categories in human genetics research. Am J Hum Genet 2005;77(4):519-532.

7. Goldstein DB, Hirschhorn JN. In genetic control of disease, does "race" matter? Nat Genet 2004;36(12):1243-1244.

8. Yaeger R, Avila-Bront A, Abdul K, et al. Comparing genetic ancestry and self-described race in african americans born in the United States and in Africa. Cancer Epidemiol Biomarkers Prev 2008;17(6):1329-1338.

9. Yang JJ, Burchard EG, Choudhry S, et al. Differences in allergic sensitization by selfreported race and genetic ancestry. J Allergy Clin Immunol 2008;122(4):820-827.e9.

10. Kumar et al. - 2010 - Genetic Ancestry in Lung-Function Predictions.pdf.

11. Graham BL, Steenbruggen I, Miller MR, et al. Standardization of Spirometry 2019 Update. An Official American Thoracic Society and European Respiratory Society Technical Statement. Am J Respir Crit Care Med 2019;200(8):e70-e88.

12. Quanjer PH, Stanojevic S, Enright PL, et al. MULTI-ETHNIC REFERENCE VALUES FOR SPIROMETRY FOR THE 3-95 YEAR. 2012;39:11.

13. Myers JE. Differential ethnic standards for lung functions, or one standard for all? S Afr Med $J$ 1984;65(19):768-772.

14. Chien JW, Sullivan KM. Carbon monoxide diffusion capacity: how low can you go for hematopoietic cell transplantation eligibility? Biol Blood Marrow Transplant 2009;15(4):447-453.

15. Fulambarker A, Copur AS, Javeri A, Jere S, Cohen ME. Reference Values for Pulmonary Function in Asian Indians Living in the United States. Chest 2004;126(4):1225-1233. 
medRxiv preprint doi: https://doi.org/10.1101/2021.06.25.21253647; this version posted June 30, 2021. The copyright holder for this preprint (which was not certified by peer review) is the author/funder, who has granted medRxiv a license to display the preprint in perpetuity. All rights reserved. No reuse allowed without permission.

RACIAL/ETHNIC-BASED SPIROMETRY: ACCURACY FOR ADMIXED

16. Hankinson JL, Kawut SM, Shahar E, Smith LJ, Stukovsky KH, Barr RG. Performance of American Thoracic Society-Recommended Spirometry Reference Values in a Multiethnic Sample of Adults. Chest 2010;137(1):138-145.

17. Korotzer B, Ong S, Hansen JE. Ethnic Differences in Pulmonary Function in Healthy Nonsmoking Asian-Americans and European-Americans. Am J Respir Crit Care Med 2000;161(4):1101-1108.

18. LaVange L, Davis SM, Hankinson J, et al. Spirometry Reference Equations from the HCHS/SOL (Hispanic Community Health Study/Study of Latinos). Am J Respir Crit Care Med 2017;196(8):993-1003.

19. Borrell LN, Elhawary JR, Fuentes-Afflick E, et al. Race and Genetic Ancestry in Medicine A Time for Reckoning with Racism. N Engl J Med 2021;

20. Quanjer PH, Pretto JJ, Brazzale DJ, Boros PW. Grading the severity of airways obstruction: new wine in new bottles. Eur Respir J 2014;43(2):505-512.

21. Hall GL, Thompson BR, Stanojevic S, et al. The Global Lung Initiative 2012 reference values reflect contemporary Australasian spirometry: Global Lung Initiative reference values. Respirology 2012;17(7):1150-1151.

22. Bonner R, Lum S, Stocks J, Kirkby J, Wade A, Sonnappa S. Applicability of the Global Lung Function Spirometry Equations in Contemporary Multiethnic Children. :2.

23. Brazzale DJ, Hall GL, Pretto JJ. Effects of adopting the new global lung function initiative 2012 reference equations on the interpretation of spirometry. Respiration 2013;86(3):183189.

24. Hulo S, Broucker V de, Giovannelli J, et al. Global Lung Function Initiative reference equations better describe a middle-aged, healthy French population than the European Community for Steel and Coal values. Eur Respir J 2016;48(6):1779-1781.

25. Belo J. Reference values for spirometry in elderly individuals: a cross-sectional study of different reference equations. 2018;9.

26. Kumar R, Seibold MA, Aldrich MC, et al. Genetic Ancestry in Lung-Function Predictions. $N$ Engl J Med 2010;363(4):321-330.

27. Brehm JM, Acosta-Pérez E, Klei L, et al. African ancestry and lung function in Puerto Rican children. Journal of Allergy and Clinical Immunology 2012;129(6):1484-1490.e6.

28. Pino-Yanes M, Thakur N, Gignoux CR, et al. Genetic ancestry influences asthma susceptibility and lung function among Latinos. Journal of Allergy and Clinical Immunology 2015;135(1):228-235. 
medRxiv preprint doi: https://doi.org/10.1101/2021.06.25.21253647; this version posted June 30, 2021. The copyright holder for this preprint (which was not certified by peer review) is the author/funder, who has granted medRxiv a license to display the preprint in perpetuity. All rights reserved. No reuse allowed without permission.

RACIAL/ETHNIC-BASED SPIROMETRY: ACCURACY FOR ADMIXED

29. Nishimura KK, Galanter JM, Roth LA, et al. Early-Life Air Pollution and Asthma Risk in Minority Children. The GALA II and SAGE II Studies. Am J Respir Crit Care Med 2013;188(3):309-318.

30. Miller MR. Standardisation of spirometry. European Respiratory Journal 2005;26(2):319338.

31. Hoffmann TJ, Zhan Y, Kvale MN, et al. Design and coverage of high throughput genotyping arrays optimized for individuals of East Asian, African American, and Latino race/ethnicity using imputation and a novel hybrid SNP selection algorithm. Genomics 2011;98(6):422430 .

32. Theodore Lytras. rspiro: Implementation of Spirometry Equations [Internet]. 2020. Available from: https://github.com/thlytras/rspiro

33. R Core Team. R: A Language and Environment for Statistical Computing [Internet]. Vienna, Austria: R Foundation for Statistical Computing; 2020. Available from: https://www.Rproject.org/

34. Thompson BR, Stanojevic S, Abramson MJ, et al. The all-age spirometry reference ranges reflect contemporary Australasian spirometry. Respirology 2011;16(6):912-917.

35. Ben Saad H, El Attar MN, Hadj Mabrouk K, et al. The recent multi-ethnic global lung initiative 2012 (GLI2012) reference values don't reflect contemporary adult's North African spirometry. Respir Med 2013;107(12):2000-2008.

36. Lakens D. Equivalence Tests: A Practical Primer for $\mathrm{t}$ Tests, Correlations, and MetaAnalyses. Soc Psychol Personal Sci 2017;8(4):355-362.

37. Bryc K, Durand EY, Macpherson JM, Reich D, Mountain JL. The genetic ancestry of African Americans, Latinos, and European Americans across the United States. Am J Hum Genet 2015;96(1):37-53.

38. Celedón JC, Roman J, Schraufnagel DE, Thomas A, Samet J. Respiratory health equality in the United States. The American thoracic society perspective. Ann Am Thorac Soc 2014;11(4):473-479.

39. The Annie E. Casey Foundation. Child population by race in the United States [Internet]. Kids Count Data Center. Available from: https://datacenter.kidscount.org/data/tables/103child-population-byrace\#detailed/1/any/false/1729,37,871,870,573,869,36,868,867,133/68,69,67,12,70,66,71,7 $2 / 423,424$

40. Arigliani M, Canciani MC, Mottini G, et al. Evaluation of the Global Lung Initiative 2012 Reference Values for Spirometry in African Children. Am J Respir Crit Care Med 2017;195(2):229-236. 
medRxiv preprint doi: https://doi.org/10.1101/2021.06.25.21253647; this version posted June 30, 2021. The copyright holder for this preprint

(which was not certified by peer review) is the author/funder, who has granted medRxiv a license to display the preprint in perpetuity.

All rights reserved. No reuse allowed without permission.

RACIAL/ETHNIC-BASED SPIROMETRY: ACCURACY FOR ADMIXED

412

413

414

415

416

417

418

419

420

421

422

423

424

425

426

427

428

429

430

431

432
41. Centers for Disease Control and Prevention (CDC). Table 2-1 Lifetime Asthma Prevalence Percents by Age, United States: National Health Interview Survey, 2018 [Internet]. 2019 [cited 2021 Feb 4];Available from: https://www.cdc.gov/asthma/nhis/2018/table2-1.htm

42. Health, United States, 2010: With Special Feature on Death and Dying. Hyattsville (MD): National Center for Health Statistics (US); 2011.

43. United States Census Bureau. Hispanic or Latino Origin by Race. Table ID: 803002 [Internet]. 2020;Available from:

https://data.census.gov/cedsci/table?q=HISPANIC\%20OR\%20LATINO\%20ORIGIN\%20B Y\%20RACE\&t=Hispanic\%20or\%20Latino\&tid=ACSDT1 Y2019.B03002\&hidePreview=f alse

44. United States Census Bureau. Quick Facts: Puerto Rico [Internet]. 2020;Available from: https://www.census.gov/quickfacts/PR

45. Quanjer PH, Stocks J, Cole TJ, Hall GL, Stanojevic S. Influence of secular trends and sample size on reference equations for lung function tests. Eur Respir J 2011;37(3):658664.

46. Stocks J, Sonnappa S, Lum S. Lung function testing in children: importance of race and ethnic-specific reference equations. Expert Review of Respiratory Medicine 2014;8(5):527531.

47. Kirkby J, Bonner R, Lum S, et al. Interpretation of pediatric lung function: impact of ethnicity. Pediatr Pulmonol 2013;48(1):20-26. 
medRxiv preprint doi: https://doi.org/10.1101/2021.06.25.21253647; this version posted June 30, 2021. The copyright holder for this preprint (which was not certified by peer review) is the author/funder, who has granted medRxiv a license to display the preprint in perpetuity. All rights reserved. No reuse allowed without permission.

RACIAL/ETHNIC-BASED SPIROMETRY: ACCURACY FOR ADMIXED

Table 1. Distribution of selected characteristics for participants in GALA II and SAGE based on race/ethnicity and genetic ancestry categories: 2006-2014.

\begin{tabular}{|c|c|c|c|c|c|c|}
\hline & \multicolumn{3}{|c|}{$\begin{array}{r}\text { African American Children } \\
\text { African Ancestry } \\
\text { (Median: } 81.3 \% \text { ) }\end{array}$} & \multicolumn{3}{|c|}{$\begin{array}{r}\text { Puerto Rican Children } \\
\text { African Ancestry } \\
\text { (Median: } 21.3 \% \text { ) }\end{array}$} \\
\hline & $\begin{array}{c}\text { All } \\
(N=275)\end{array}$ & $\begin{array}{l}\leq \text { Median } \\
(\mathrm{N}=138)\end{array}$ & $\begin{array}{l}\text { >Median } \\
(N=137)\end{array}$ & $\begin{array}{c}\text { All } \\
(N=324)\end{array}$ & $\begin{array}{l}\leq \text { Median } \\
(\mathrm{N}=162)\end{array}$ & $\begin{array}{l}\text { >Median } \\
(\mathrm{N}=162)\end{array}$ \\
\hline Boys, \% & 41 & 43 & 39 & 45 & 43 & 48 \\
\hline Age, year & $16.2(3.8)$ & $15.9(3.9)$ & $16.5(3.7)$ & $14.0(3.0)$ & $14.2(3.2)$ & $13.8(2.7)$ \\
\hline Height, $\mathrm{cm}$ & $\begin{array}{l}162.3 \\
(13.6)\end{array}$ & $\begin{array}{l}161.4 \\
(13.6)\end{array}$ & $\begin{array}{l}163.1 \\
(13.6)\end{array}$ & $\begin{array}{l}158.6 \\
(11.6)\end{array}$ & $\begin{array}{l}157.9 \\
(12.7)\end{array}$ & $\begin{array}{l}159.4 \\
(10.3)\end{array}$ \\
\hline $\begin{array}{l}\text { Weight, } \mathrm{kg} \\
\text { Ancestry, } \\
\%\end{array}$ & $67.3(24.4)$ & $66.1(22.7)$ & $68.4(26.1)$ & $57.8(18.8)$ & $56.6(16.9)$ & $59.0(20.5)$ \\
\hline African & $79.5(9.6)$ & $73.2(9.6)$ & $85.9(3.2)^{*}$ & $22.7(10.5)$ & $15.1(3.3)$ & $30.2(9.8)^{*}$ \\
\hline Native & - & - & - & $10.2(3.1)$ & $10.6(3.5)$ & $9.8(2.7)^{*}$ \\
\hline $\mathrm{zFEV}_{1}$ & $0.35(0.95)$ & $0.41(0.97)$ & $0.29(0.94)$ & $0.56(1.21)$ & $0.69(1.14)$ & $0.43(1.28)^{*}$ \\
\hline $\mathrm{zFVC}$ & $0.49(0.99)$ & $0.56(0.97)$ & $0.43(1.01)$ & $0.39(1.27)$ & $0.55(1.15)$ & $0.23(1.36)^{*}$ \\
\hline
\end{tabular}

Definition of abbreviations: $\mathrm{zFEV}_{1}=\mathrm{z}$-score for $\mathrm{FEV}_{1}$; $\mathrm{zFVC}=\mathrm{z}$-score for $\mathrm{FVC}$.

Results are presented as mean (SD) unless otherwise specified. Spirometry z-scores based on Global Lung Function Initiative 2012 equations, using the African American-derived equation for African American children and the composite equation for Puerto Rican children. ${ }^{5}$ *Differences between subpopulations: $P<0.05$ (Student's t-test and Wilcoxon Rank Sum Test). 
medRxiv preprint doi: https://doi.org/10.1101/2021.06.25.21253647; this version posted June 30, 2021. The copyright holder for this preprint (which was not certified by peer review) is the author/funder, who has granted medRxiv a license to display the preprint in perpetuity. All rights reserved. No reuse allowed without permission.

RACIAL/ETHNIC-BASED SPIROMETRY: ACCURACY FOR ADMIXED

Table 2a. Fit of Spirometry Equation Predictions to Spirometric Measurements in African American Children: 2006-2014

\begin{tabular}{|c|c|c|c|}
\hline & \multirow[b]{2}{*}{$\begin{array}{c}\text { All } \\
(N=275)\end{array}$} & \multicolumn{2}{|c|}{ African Ancestry } \\
\hline & & $\begin{array}{c}\leq \text { Median } \\
\text { 30.7 to } 81.3 \% \\
(\mathbf{N}=138) \\
\end{array}$ & $\begin{array}{c}\text { > Median } \\
81.4 \text { to } 100 \% \\
(\mathrm{~N}=137)\end{array}$ \\
\hline \multicolumn{4}{|l|}{$\mathrm{zFEV}_{1}$} \\
\hline NHANES III, White & $\begin{array}{l}-0.95(-1.07,-0.84) \\
{[24.0 \%]}\end{array}$ & $\begin{array}{l}-0.88(-1.04,-0.73) \\
{[23.9 \%]}\end{array}$ & $\begin{array}{l}-1.03(-1.19,-0.86) \\
{[24.1 \%]}\end{array}$ \\
\hline NHANES III, African & $0.17(0.06,0.28)^{* \dagger}$ & $0.24(0.08,0.39)^{*}$ & $0.11(-0.04,0.26)^{* \dagger}$ \\
\hline American & {$[2.5 \%]$} & {$[2.2 \%]$} & [2.9\%] \\
\hline NHANES III, Mexican & $-1.19(-1.30,-1.07)$ & $-1.12(-1.27,-0.96)$ & $-1.26(-1.42,-1.09)$ \\
\hline American & [31.6\%] & [28.3\%] & {$[35.0 \%]$} \\
\hline GLI, White & $\begin{array}{l}-0.88(-0.99,-0.77) \\
{[18.2 \%]}\end{array}$ & $\begin{array}{l}-0.82(-0.97,-0.67) \\
{[18.8 \%]}\end{array}$ & $\begin{array}{l}-0.94(-1.09,-0.79) \\
{[17.5 \%]}\end{array}$ \\
\hline GLI, African American & $\begin{array}{l}0.35(0.24,0.46)^{*} \\
{[1.8 \%]}\end{array}$ & $\begin{array}{l}0.41(0.25,0.58) \\
{[1.4 \%]}\end{array}$ & $\begin{array}{l}0.29(0.13,0.44)^{*} \\
{[2.2 \%]}\end{array}$ \\
\hline GLI, Composite & $\begin{array}{l}-0.32(-0.43,-0.20)^{* \dagger} \\
{[5.8 \%]}\end{array}$ & $\begin{array}{l}-0.25(-0.42,-0.09)^{* \dagger} \\
{[5.8 \%]}\end{array}$ & $\begin{array}{l}-0.38(-0.54,-0.22) \\
{[5.8 \%]}\end{array}$ \\
\hline \multicolumn{4}{|l|}{ zFVC } \\
\hline NHANES III, White & $\begin{array}{l}-0.85(-0.97,-0.74) \\
{[19.3 \%]}\end{array}$ & $\begin{array}{l}-0.79(-0.94,-0.63) \\
{[14.5 \%]}\end{array}$ & $\begin{array}{l}-0.92(-1.09,-0.75) \\
{[24.1 \%]}\end{array}$ \\
\hline NHANES III, African & $0.34(0.23,0.45)^{* \dagger}$ & $0.41(0.26,0.56)$ & $0.27(0.10,0.43)^{* \dagger}$ \\
\hline American & {$[1.8 \%]$} & {$[0.7 \%]$} & {$[2.9 \%]$} \\
\hline NHANES III, Mexican & $-1.00(-1.11,-0.88)$ & $-0.93(-1.09,-0.77)$ & $-1.06(-1.23,-0.90)$ \\
\hline American & {$[24.0 \%]$} & {$[21.0 \%]$} & {$[27.0 \%]$} \\
\hline GLI, White & $\begin{array}{l}-0.79(-0.91,-0.68) \\
{[17.8 \%]}\end{array}$ & $\begin{array}{l}-0.74(-0.89,-0.58) \\
{[14.5 \%]}\end{array}$ & $\begin{array}{l}-0.85(-1.01,-0.69) \\
{[21.2 \%]}\end{array}$ \\
\hline GLI, African American & $\begin{array}{l}0.49(0.37,0.61) \\
{[2.2 \%]}\end{array}$ & $\begin{array}{l}0.56(0.39,0.72) \\
{[1.4 \%]}\end{array}$ & $\begin{array}{l}0.43(0.26,0.60) \\
{[2.9 \%]}\end{array}$ \\
\hline GLI, Composite & $\begin{array}{l}-0.14(-0.27,-0.02)^{* \dagger} \\
{[6.2 \%]}\end{array}$ & $\begin{array}{l}-0.08(-0.25,0.10)^{* \dagger} \\
{[5.8 \%]}\end{array}$ & $\begin{array}{l}-0.21(-0.39,-0.02)^{*} \\
{[6.6 \%]}\end{array}$ \\
\hline
\end{tabular}

Definition of abbreviations: NHANES III = Third National Health and Nutrition Examination Survey; GLI = Global Lung Function Initiative; $\mathrm{zFEV}_{1}=\mathrm{z}$-score for $\mathrm{FEV}_{1}$; $\mathrm{zFVC}=\mathrm{z}$-score for FVC.

Results are presented as mean (95\% confidence interval) [percent below the fifth percentile]. *Equation provides sufficient fit: mean z-score $<|0.5|(P<0.05)$ with $95 \%$ confidence intervals inside interval $[-0.5,0.5]) .^{21,34,35}$

${ }^{\dagger}$ Equation appropriate for population/subpopulation (provides sufficient fit for both $\mathrm{FEV}_{1}$ and FVC). 
medRxiv preprint doi: https://doi.org/10.1101/2021.06.25.21253647; this version posted June 30, 2021. The copyright holder for this preprint (which was not certified by peer review) is the author/funder, who has granted medRxiv a license to display the preprint in perpetuity. All rights reserved. No reuse allowed without permission.

RACIAL/ETHNIC-BASED SPIROMETRY: ACCURACY FOR ADMIXED

Table 2b. Fit of Spirometry Equation Predictions to Spirometric Measurements in Puerto Rican Children: 2006-2014

\begin{tabular}{|c|c|c|c|}
\hline & & African & Ancestry \\
\hline & $\begin{array}{c}\text { All } \\
(\mathrm{N}=\mathbf{3 2 4})\end{array}$ & $\begin{array}{c}\leq \text { Median } \\
6.4 \text { to } 21.3 \% \\
(N=162)\end{array}$ & $\begin{array}{c}>\text { Median } \\
21.4 \text { to } 87.5 \% \\
(\mathrm{~N}=162)\end{array}$ \\
\hline $\mathrm{zFEV}_{1}$ & & & \\
\hline NHANES III, White & $\begin{array}{l}-0.16(-0.28,-0.04)^{*} \\
{[7.1 \%]}\end{array}$ & $\begin{array}{l}-0.05(-0.21,0.12)^{* \dagger} \\
{[4.9 \%]}\end{array}$ & $\begin{array}{l}-0.27(-0.46,-0.09)^{*} \\
{[9.3 \%]}\end{array}$ \\
\hline NHANES III, African & $0.90(0.78,1.02)$ & $1.02(0.86,1.18)$ & $0.78(0.60,0.96)$ \\
\hline American & {$[0.3 \%]$} & {$[0.0 \%]$} & {$[0.6 \%]$} \\
\hline NHANES III, Mexican & $-0.41(-0.53,-0.28)$ & $-0.28(-0.45,-0.12)^{*}$ & $-0.53(-0.72,-0.35)$ \\
\hline American & {$[11.7 \%]$} & {$[9.3 \%]$} & {$[14.2 \%]$} \\
\hline GLI, White & $\begin{array}{l}-0.06(-0.19,0.06)^{* \dagger} \\
{[6.8 \%]}\end{array}$ & $\begin{array}{l}0.06(-0.11,0.22)^{* \dagger} \\
{[4.3 \%]}\end{array}$ & $\begin{array}{l}-0.18(-0.36,0.01)^{*} \\
{[9.3 \%]}\end{array}$ \\
\hline GLI, African American & $\begin{array}{l}1.23(1.10,1.36) \\
{[0.3 \%]}\end{array}$ & $\begin{array}{l}1.35(1.18,1.53) \\
{[0.0 \%]}\end{array}$ & $\begin{array}{l}1.10(0.91,1.30) \\
{[0.6 \%]}\end{array}$ \\
\hline GLI, Composite & $\begin{array}{l}0.56(0.43,0.69) \\
{[1.5 \%]}\end{array}$ & $\begin{array}{l}0.69(0.51,0.86) \\
{[0.6 \%]}\end{array}$ & $\begin{array}{l}0.43(0.24,0.63) \\
{[2.5 \%]}\end{array}$ \\
\hline $\mathrm{zFVC}$ & & & \\
\hline NHANES III, White & $\begin{array}{l}-0.41(-0.53,-0.30) \\
{[12.0 \%]}\end{array}$ & $\begin{array}{l}-0.28(-0.43,-0.12)^{* \dagger} \\
{[7.4 \%]}\end{array}$ & $\begin{array}{l}-0.55(-0.73,-0.37) \\
{[16.7 \%]}\end{array}$ \\
\hline NHANES III, African & $0.76(0.64,0.87)$ & $0.89(0.74,1.05)$ & $0.62(0.44,0.80)$ \\
\hline American & {$[0.6 \%]$} & {$[0.0 \%]$} & {$[1.2 \%]$} \\
\hline NHANES III, Mexican & $-0.56(-0.68,-0.44)$ & $-0.42(-0.58,-0.27)$ & $-0.70(-0.88,-0.52)$ \\
\hline American & {$[15.7 \%]$} & {$[10.5 \%]$} & {$[21.0 \%]$} \\
\hline GLI, White & $\begin{array}{l}-0.33(-0.46,-0.21)^{* \dagger} \\
{[11.1 \%]}\end{array}$ & $\begin{array}{l}-0.19(-0.35,-0.03)^{* \dagger} \\
{[6.8 \%]}\end{array}$ & $\begin{array}{l}-0.48(-0.66,-0.29) \\
{[15.4 \%]}\end{array}$ \\
\hline GLI, African American & $\begin{array}{l}1.00(0.87,1.13) \\
{[0.6 \%]}\end{array}$ & $\begin{array}{l}1.15(0.98,1.32) \\
{[0.0 \%]}\end{array}$ & $\begin{array}{l}0.86(0.66,1.06) \\
{[1.2 \%]}\end{array}$ \\
\hline GLI, Composite & $\begin{array}{l}0.39(0.25,0.53) \\
{[4.3 \%]}\end{array}$ & $\begin{array}{l}0.55(0.37,0.73) \\
{[1.9 \%]}\end{array}$ & $\begin{array}{l}0.23(0.02,0.44)^{*} \\
{[6.8 \%]}\end{array}$ \\
\hline
\end{tabular}

Definition of abbreviations: NHANES III = Third National Health and Nutrition Examination Survey; GLI = Global Lung Function Initiative; $\mathrm{zFEV}_{1}=\mathrm{z}$-score for $\mathrm{FEV}_{1}$; $\mathrm{zFVC}=\mathrm{z}$-score for FVC.

Results are presented as mean (95\% confidence interval) [percent below the fifth percentile].

*Equation provides sufficient fit: mean z-score $<|0.5|(P<0.05)$ with $95 \%$ confidence intervals inside interval $[-0.5,0.5]) .^{21,34,35}$

${ }^{\dagger}$ Equation appropriate for population/subpopulation (provides sufficient fit for both $\mathrm{FEV}_{1}$ and FVC). 
medRxiv preprint doi: https://doi.org/10.1101/2021.06.25.21253647; this version posted June 30, 2021. The copyright holder for this preprint (which was not certified by peer review) is the author/funder, who has granted medRxiv a license to display the preprint in perpetuity. All rights reserved. No reuse allowed without permission.

RACIAL/ETHNIC-BASED SPIROMETRY: ACCURACY FOR ADMIXED

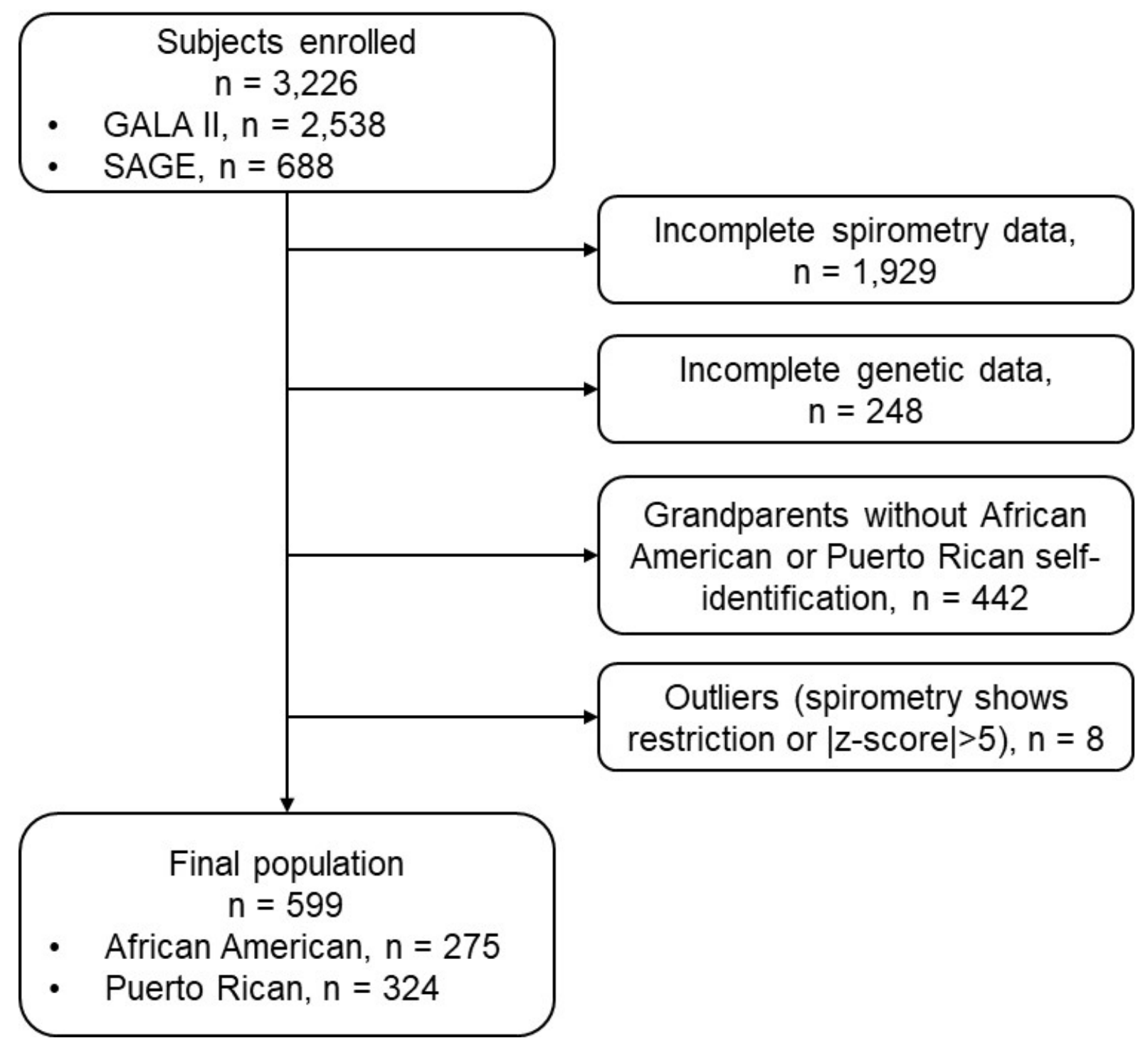

Figure 1. Study population. African American and Puerto Rican children (8-21 years old) recruited as part of parallel case-control studies of asthma from the Genes-environments \& Admixture in Latino Americans (GALA II) study and the Study of African Americans, Asthma, Genes, \& Environments (SAGE). 
medRxiv preprint doi: https://doi.org/10.1101/2021.06.25.21253647; this version posted June 30, 2021. The copyright holder for this preprint (which was not certified by peer review) is the author/funder, who has granted medRxiv a license to display the preprint in perpetuity.

All rights reserved. No reuse allowed without permission.

RACIAL/ETHNIC-BASED SPIROMETRY: ACCURACY FOR ADMIXED
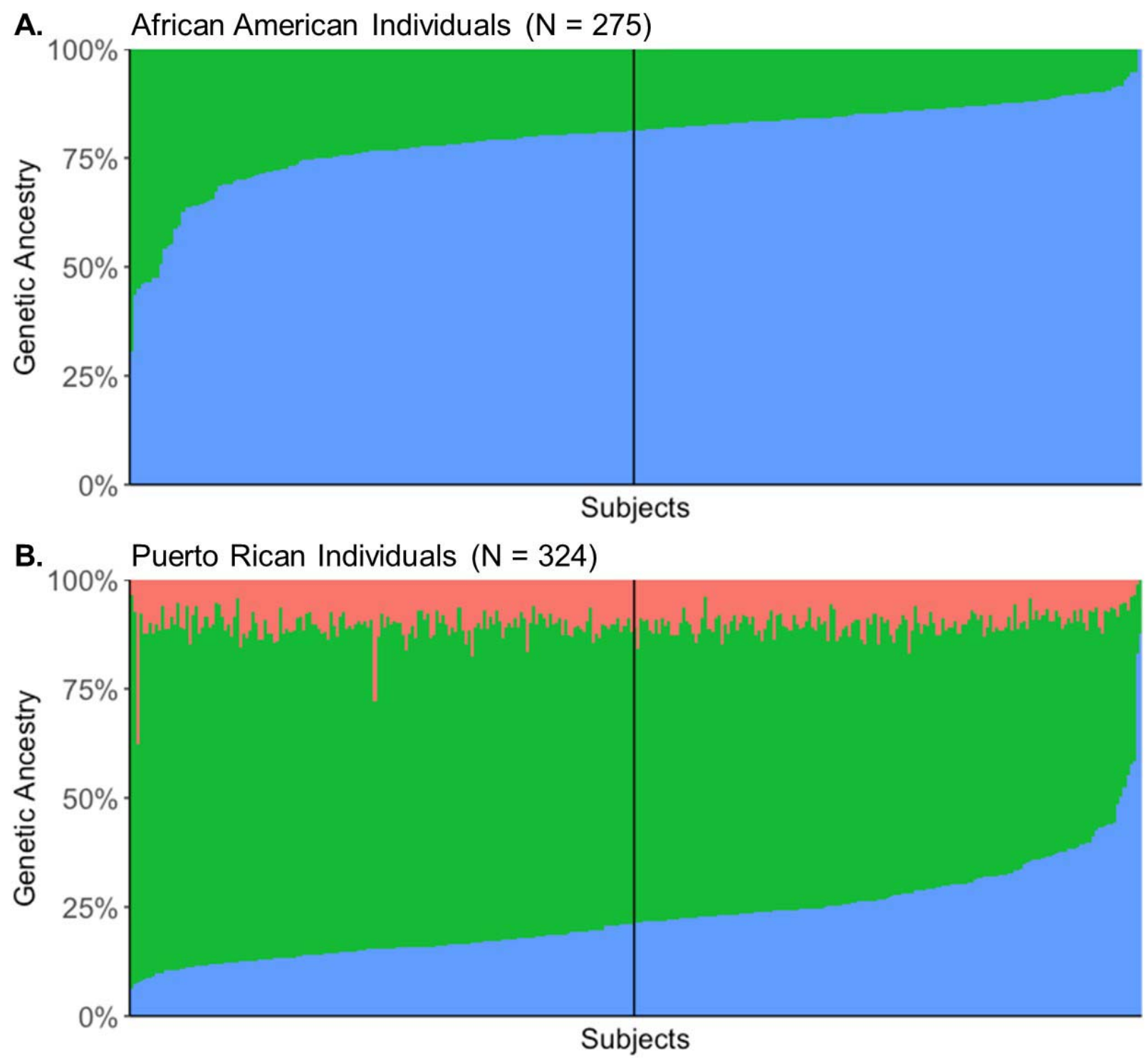

Native American $\square$ European $\square$ African

Figure 2. Genetic admixture in the (A) African Americanand (B) Puerto Rican children. The vertical black lines partition each population into paired subpopulations based on proportions of genetic ancestry. The African American and Puerto Rican subpopulations include individuals with African ancestry above and below the median. 
A

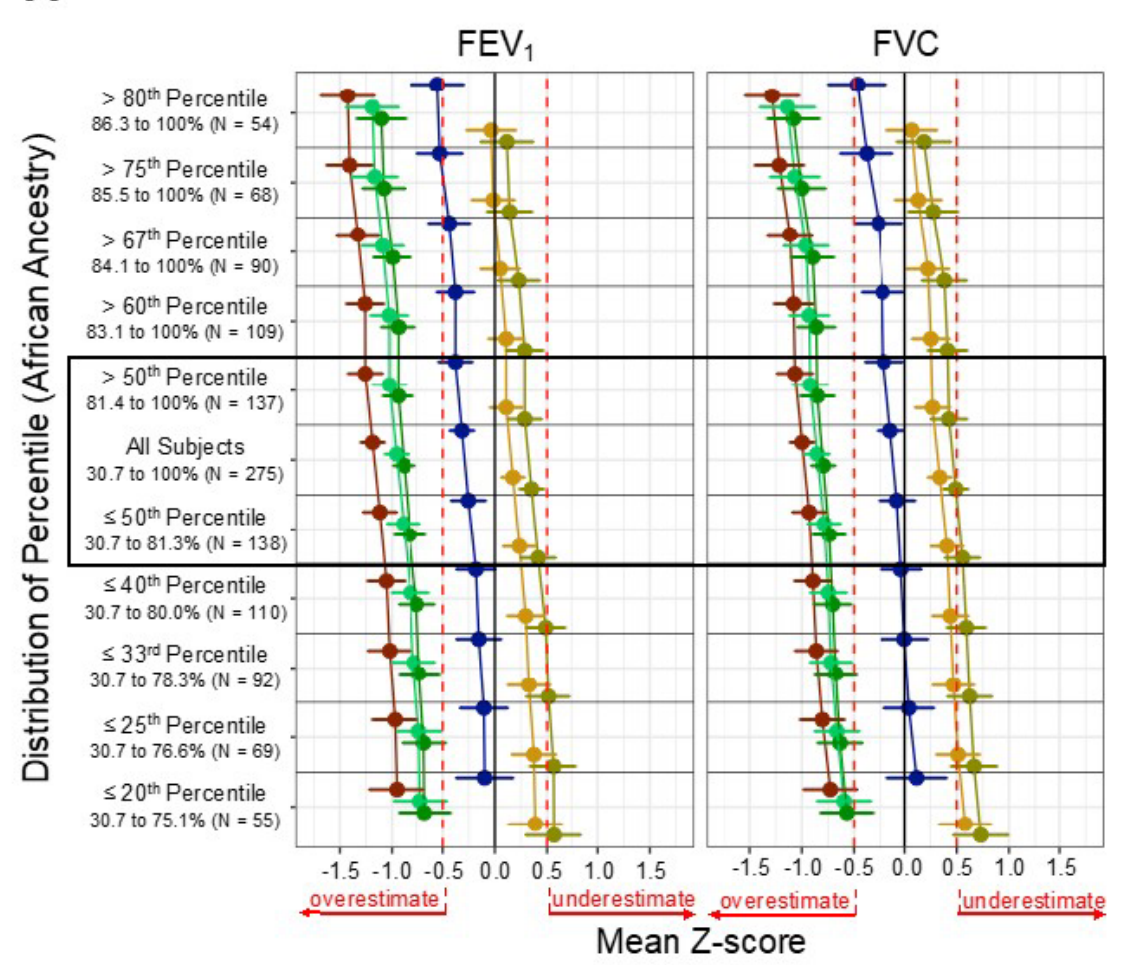

B

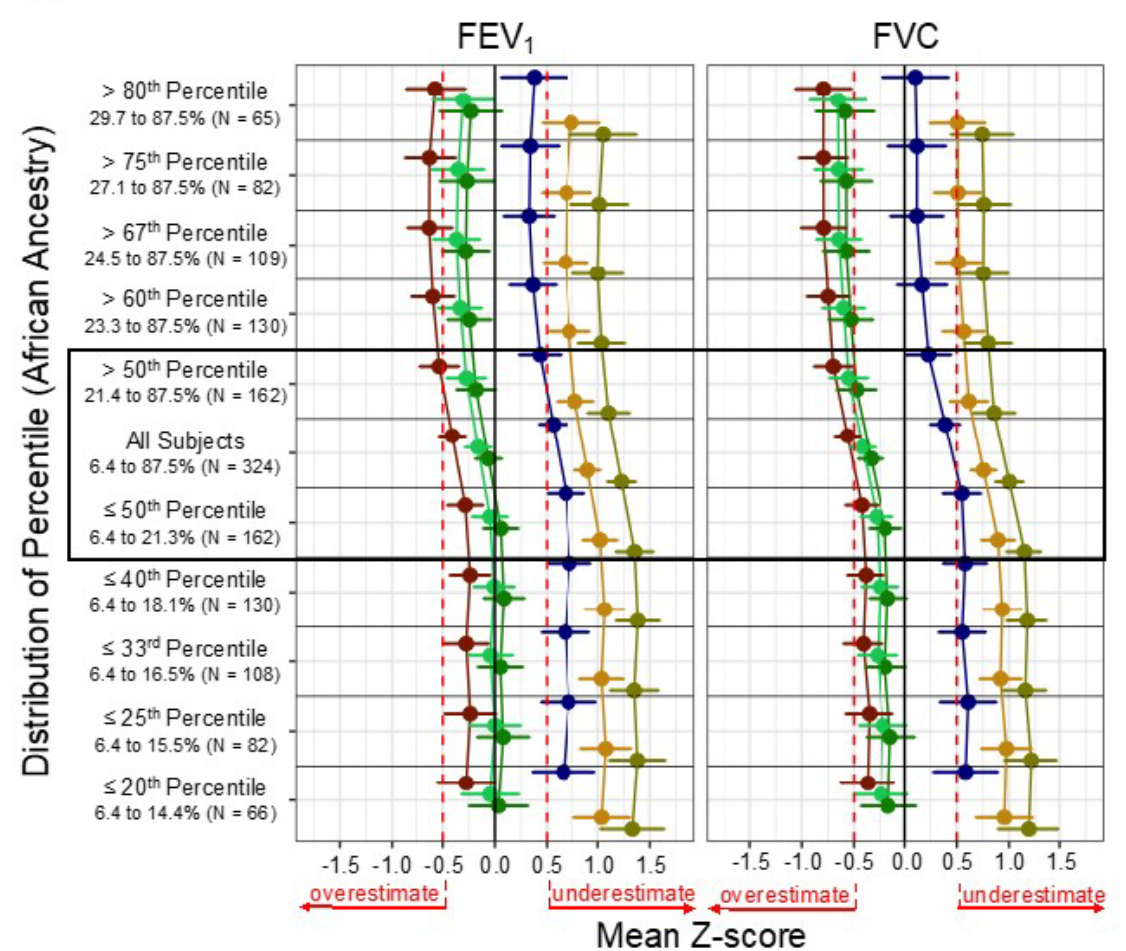

Reference Equation

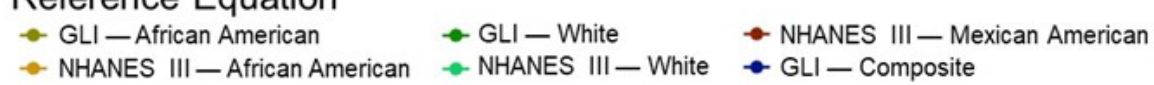

Figure 3. Spirometry reference equation fit for predicting $\mathrm{FEV}_{1}$ and FVC in (A) African American and (B) Puerto Rican children with sensitivity analysis showing equation fit in subpopulations with increasingly disparate proportions of genetic ancestry, including ancestry tertiles, quartiles, and quintiles. Dot-and-whisker plots show mean z-score with $95 \%$ confidence intervals for each population/subpopulation. Solid black vertical lines indicate mean z-score of zero (perfect equation fit). Dashed red vertical lines indicate the interval $[-0.5,0.5]$ ) for sufficient equation fit. Black boxes outline the primary analysis of the study with sensitivity analysis above and below. 